\title{
PEMETAAN JENIS DONGENG NUSANTARA DALAM INFOGRAFIS
}

\author{
Rizki Taufik Rakhman', Yasraf Amir Piliang², Hafiz Aziz Ahmad³, Iwan Gunawan ${ }^{4}$ \\ ${ }^{1,2,3}$ Program Doktor Ilmu Seni Rupa dan Desain, Fakultas Seni Rupa dan Desain, ITB Bandung \\ ${ }^{4}$ Program Doktoral, Fakultas Seni Rupa dan Desain, Institut Kesenian Jakarta \\ rizkitaufikrakhman@itb.ac.id ${ }^{1}$
}

\begin{abstract}
Abstrak
Dongeng merupakan warisan budaya lisan yang bersifat mendidik sekaligus menghibur. Sebagai warisan budaya lisan, keberadaan dongeng wajib dilestarikan agar tidak punah. Pada kenyataannya, generasi Z (Gen Z) Indonesia memiliki jarak dengan dongeng. Hal ini diketahui melalui kuesioner yang dibagikan kepada 70 siswa sekolah dasar kelas 3, 4, dan 5. Menurut responden dongeng hanya diketahui melalui pelajaran Bahasa Indonesia. Selain itu, responden tidak mengetahui secara pasti jenis-jenis dongeng nusantara. Penelitian ini bertujuan untuk memantik perhatian (awareness) Gen Z Indonesia terhadap jenis-jenis dongeng nusantara. Pendekatan dilakukan melalui bentuk infografis yang diasumsikan dapat mempermudah Gen Z Indonesia dalam memperoleh informasi, memahami hingga menyadari adanya dongeng. Metode yang digunakan dalam penelitian adalah metode campuran. Hasil pendekatan kuantitatif melalui kuesioner kemudian dianalisa dan dikonfirmasi ulang melalui wawancara dengan para responden melalui pendekatan kualitatif. Hasil wawancara menjadi rujukan dalam mengolah data menjadi pemetaan jenis-jenis dongeng nusantara ke dalam bentuk infografis. Selanjutnya infografis peta jenis dongeng nusantara diujicobakan melalui diskusi dengan kelompok responden yang terdiri dari generasi $Z$ yang dipilih secara acak. Meskipun hasil yang didapat belum optimal, namun simpulan awal dari penelitian ini adalah generasi $Z$ Indonesia mulai memperhatikan (aware) berbagai jenis dongeng nusantara sebagai warisan budaya lisan bangsa Indonesia yang harus dilestarikan.
\end{abstract}

Kata Kunci: generasi Z, infografis, dongeng nusantara, pemetaan

\begin{abstract}
Fairy tales are a verbal cultural heritage that is educating and entertaining. As a verbal cultural heritage, fairy tales' existence must preserve so as not extinct. In reality, Indonesian generation $Z$ (Gen Z) has a distance from fairy tales. It's known through a questionnaire distributed to 70 elementary school students in grades 3, 4, and 5. According to them, fairy tales are known only through Bahasa Indonesia subjects. Besides, they do not know for sure the types of Indonesian archipelago fairy tales. This research aims to arise Indonesian Gen $Z$ awareness towards the types of Indonesian archipelago fairy tales. The approach taken through the form of infographics is assumed to facilitate the Indonesian Gen Z in obtaining information, understanding, and being aware of Indonesian fairy tales. The method used in this study is a mixed-method. The quantitative approach research through a questionnaire was then analyzed and reconfirmed through interviews with respondents with a qualitative approach. The interview results referred to processing the data into mapping the types of tales of the Indonesian archipelago into infographics. Furthermore, the Indonesian archipelagos fairy tale type of infographic map was tested through a group discussion consist of randomly selected Gen $Z$ respondences. Although the result not optimal, the early conclusion indicates that Indonesian Gen Z starting to become aware of the Indonesian archipelago fairy tales as the verbal cultural heritage of Indonesia that must be preserved.
\end{abstract}

Keywords: Z generation, infographic, nusantara folktales, mapping 


\section{PENDAHULUAN}

Dongeng merupakan cerita pendek kolektif kesusastraan lisan. Dongeng diceritakan semata-mata untuk hiburan, meskipun banyak melukiskan kebenaran dan berisi pesan moral maupun sindiran. Penggolongan dongeng juga memiliki perkembangan. Awalnya Grimm bersaudara (Jacob dan Wilhelm) dari German menciptakan sebuah sistem penggolongan dongeng yang kemudian juga dilakukan oleh Sven Grundtvig dari Denmark, namun kedua sistem penggolongan tidak dapat diterapkan secara internasional. Hingga di akhir abad ke-19, seorang ahli folklor asal Finlandia bernama Kaarle Krohn berhasil merintis sistem klasifikasi dongeng yang lebih umum sifatnya dan disempurnakan oleh muridnya bernama Anti Aarne. Pada tahun 1910, Anti Aarne berhasil menerbitkan buku katalogus berjudul Verzeichnis der Marchentypen (Folklore Fellows Communications, No.3) yang kemudian diterjemahkan dan dikembangkan oleh ahli folklor Amerika Serikat, Stith Thompson (Danandjaja, 1984).

Di Indonesia, objek penelitian tentang dongeng sangatlah luas. Hal ini sangat dipengaruhi oleh bentuk geografis Indonesia yang fragmented, bentuk kepulauan yang secara geografis terpisah-pisah atau dikenal dengan negara kepulauan. Sehingga perlu diketahui terlebih dahulu ciri-ciri pengenal utama untuk mengelompokkannya. Adapun ciri-ciri tersebut antara lain: (1) penyebaran dan pewarisannya dilakukan secara lisan, (2) bersifat tradisional, (3) ada dalam varian-varian berbeda, (4) bersifat anonim, (5) memiliki rumus atau berpola, (6) memiliki kegunaan dalam kehidupan, (7) milik bersama atau kolektif, (8) bersifat polos dan lugu (Danandjaja, 1984).

Dongeng merupakan salah satu warisan budaya tradisi lisan bangsa Indonesia, bahkan Pramoedya Ananta Toer mengatakan bahwa Dongeng adalah medium terindah dalam tradisi lisan nusantara. Jika dongeng menjadi rutinitas kegiatan sebelum tidur bagi generasi $Y$ atau generasi sebelumnya, berbeda dengan generasi $Z$ yang tidak terbiasa dengan hal tersebut. Prioritas dan waktu tidak menjadikan dongeng sebagai rutinitas atau sekedar kegiatan untuk mempererat ikatan hubungan keluarga. Generasi Z merupakan generasi yang lahir dan tumbuh seiring dengan perkembangan teknologi. Bagi mereka dunia maya adalah realitas itu sendiri. Sehingga kegiatan dongeng tidak lagi menjadi sebuah pilihan mereka dalam rutinitasnya.

Menurut Promedya Ananta Toer, dongeng adalah medium terindah dalam tradisi lisan Nusantara. Namun, keindahan tradisi lisan tersebut semakin lama semakin terkikis dikarenakan beberapa faktor seperti prioritas dan waktu di dalam keluarga muda saat ini. Menurut penelitian Bencsik, Csikos dan Juhez pada tahun 2016 tentang perbedaan karakteristik generasi memasukkan generasi $X$ kelahiran tahun 1960-1980, generasi $Y$ kelahiran tahun 1980-1995 dan generasi Z kelahiran tahun 1995-2010. Jika dongeng menjadi salah satu aktivitas rutin sebelum tidur bagi generasi $X$ dan $Y$ saat mereka kecil, namun saat mereka menjadi orang tua muda hal tersebut jarang atau bahkan tidak lagi dilakukan. Pernyataan diperoleh berdasarkan hasil kuesioner dan wawancara kepada 70 responden yang terdiri dari siswa dan siswa sekolah dasar kelas 3, 4 dan 5 sebagai generasi $Z$ dimana orang tuanya masuk dalam kategori generasi $\mathrm{X}$ dan $\mathrm{Y}$. Mereka mengetahui dongeng melalui Pendidikan formal di kelas pada mata pelajaran Bahasa 
Indonesia. Menurut mereka, meskipun diakui orang tua sudah menyediakan fasilitas berupa buku dongeng namun aktivitas dongeng tidak mereka lakukan bersama orang tua. Hal ini yang menjadi penyebab adanya jarak antara dongeng dengan generasi Z. Jika dengan dongeng sudah berjarak maka diasumsikan mereka tidak mengenal jenis-jenis dongeng Nusantara sebagai warisan budaya lisan bangsa Indonesia.

Hal tersebut bukanlah mutlak kesalahan dari generasi Z. Generasi sebelumnya-lah yang memiliki tanggung jawab untuk memperkenalkan dongeng sebagai warisan tradisi lisan bangsa Indonesia. Melalui penelitian berjudul, "Pemetaan Jenis Dongeng Nusantara dalam Infografis", bertujuan memperkenalkan kembali dongeng nusantara kepada generasi $Z$ melalui sebuah infografis yang menarik untuk memudahkan mereka dalam membedakan berbagai jenis dongeng nusantara. Upaya yang dilakukan penulis dengan pendekatan infografis agar mereka tertarik dan memudahkan mereka mengetahui jenisjenis dongeng Nusantara dalam berbagai kategori pembedanya. Sehingga peta jenis dongeng dapat menjadi acuan bagi generasi $Z$ Indonesia untuk memperdalam pengetahuan mereka pada dongeng Nusantara.

\section{METODE PENELITIAN}

Metode penelitian yang digunakan dalam penelitian ini adalah metode penelitian campuran (mixed method) dengan dua pendekatan; kuantitatif dan kualitatif. Teknik pengumpulan data yang dipakai pada penelitian ini adalah dokumen dan diskusi. Bentuk-bentuk dokumen seperti buku cerita dongeng, foto, jadwal kegiatan. Hal tersebut diharapkan dapat memberikan informasi deskriptif yang sangat membantu penulis dalam menganalisa data, dengan dokumen-dokumen kuantitatif ini analisa data akan lebih mendalam sesuai dengan kebutuhan penelitian. Selain itu, penulis juga melakukan observasi dimana kegiatan tidak sekedar mencatat, namun harus mempertimbangkan yang kemudian dilakukan penilaian ke dalam skala bertingkat.

Ada beberapa tahap yang dilakukan oleh penulis pada metode campuran yang digunakan. Tahap pertama, penulis menyebarkan kuesioner kepada 70 responden yang terdiri dari siswa dan siswi sekolah dasar kelas 3, 4 dan 5. Pada tahap ini juga dilakukan wawancara kepada tiap responden tentang beberapa hal yang menyangkut dongeng, jenis dongeng dan kegiatan dongeng. Hasil kuesioner sebagai pendekatan kuantitatif kemudian dianalisa dan dikonfirmasi dengan hasil wawancara sebagai pendekatan kualitatif. Hasil analisa ini kemudian dielaborasi dengan hasil studi literatur yang dilakukan penulis kepada 353 judul dongeng nusantara dari 34 provinsi yang sudah dipublikasikan oleh penerbit Karisma. 


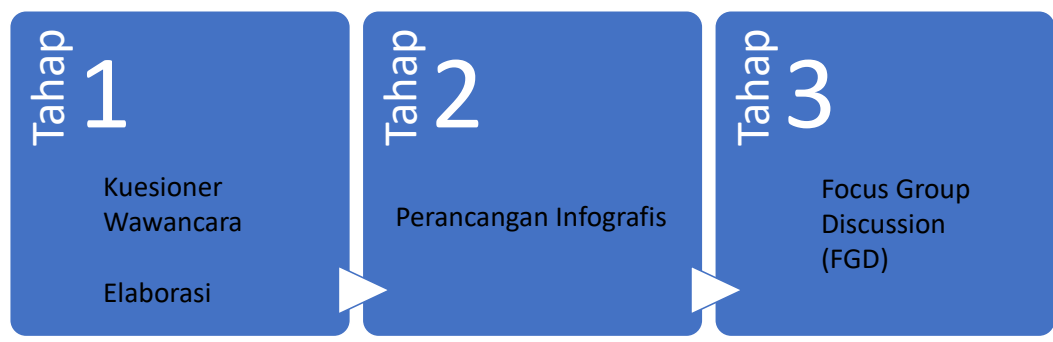

Gambar 1. Skema Tahapan Penelitian

[Sumber: Dokumentasi penulis]

Tahap kedua adalah penulis merancang sebuah infografis peta jenis dongeng nusantara dengan merujuk dari hasil elaborasi pada metode sebelumnya. Setelah rancangan infografis selesai, penulis kemudian kembali mengujicobakan melalui sebuah diskusi dengan kelompok eksperimen yang terdiri dari generasi $Z$ yang dipilih secara acak pada tahap ketiga. Focus group Discussion (FGD) dilakukan oleh penulis dengan kelompok eksperimen yang sudah dipilih secara acak sebanyak 6 orang mewakili tiap kelasnya sehingga jumlah anggota eksperimen sebanyak 18 orang.

Kegiatan pada tahap ketiga bertujuan untuk memvalidasi hasil rancangan infografis jenis dongeng nusantara yang sebelumnya sudah dibuat terlebih dahulu oleh penulis. Melalui FGD, penulis mendapat banyak sekali masukan dari kelompok eksperimen baik dari segi rancangan, informasi, hingga pemahaman mereka terhadap konten infografis itu sendiri berupa pemetaan jenis dongeng Nusantara.

\section{HASIL DAN PEMBAHASAN}

Usaha pengumpulan dan pengarsipan dongeng nusantara sudah banyak dilakukan. Yayasan Harapan Kita milik ibu Tien Soeharto membuat sebuah museum alam terbuka, Taman Mini Indonesia Indah (TMII). Konsep TMII adalah mengalokasikan kebudayaan dari seluruh Indonesia termasuk rumah adat, perabot dan perlengkapan rumah lainnya, kegiatan upacara, kesenian hingga cerita dongeng (Danandjaja, 1984). Hal ini mengusik penulis untuk melakukan observasi sekaligus validasi tentang keberadaan arsip dongeng nusantara di TMII.

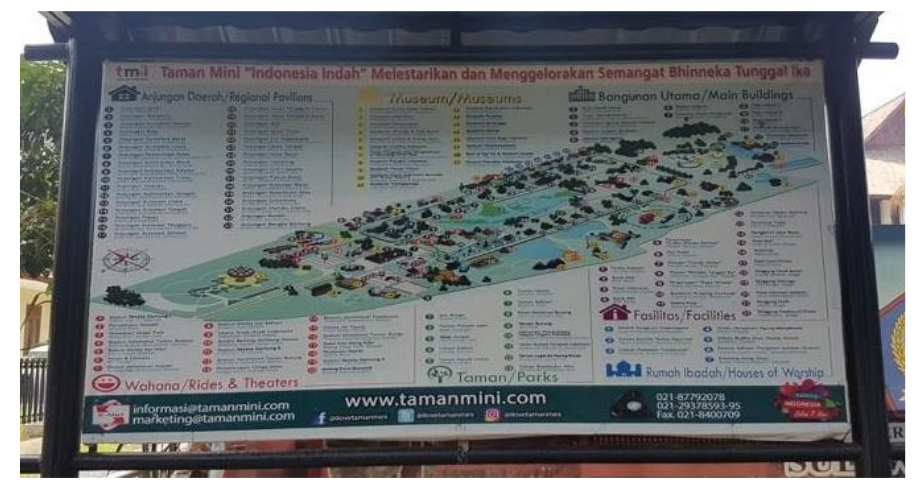

Gambar 2. Peta Anjungan di Taman Mini Indonesia Indah [Sumber: Dokumentasi Penulis, 2019] 
Hasil observasi penulis adalah sebagai berikut; 5 dari 14 anjungan yang berhasil didatangi untuk wawancara dengan petugas memiliki arsip dongeng nusantara, 4 petugas dari 9 anjungan yang tidak memiliki arsip dongeng Indonesia dapat menceritakan beberapa dongeng nusantara asal anjungan tersebut. Sebagian besar dari anjungan-anjungan yang tidak memiliki arsip dongeng Indonesia mengaku belum adanya buku atau media apapun yang memiliki konten dongeng asal anjungan tersebut.
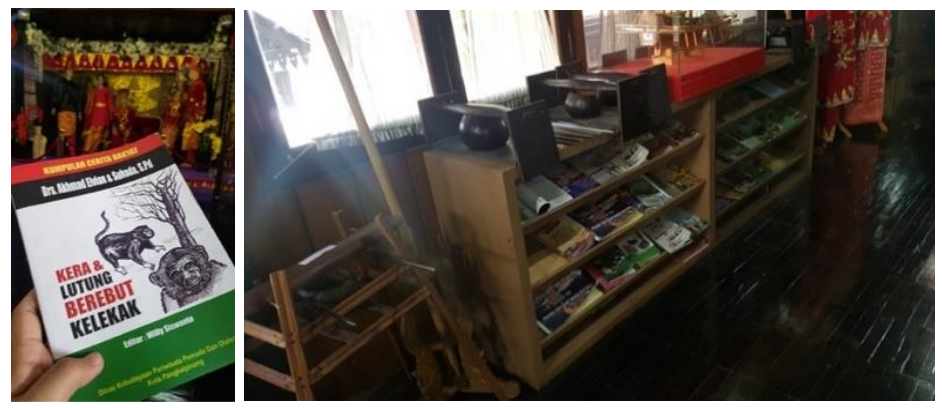

Gambar 3. Arsip Dongeng Bangka Belitung

[Sumber: Dokumentasi Penulis, 2019]

Observasi yang dilakukan oleh penulis sekaligus memvalidasi tulisan James Danandjaja pada bukunya yang berjudul, "Folklor Indonesia" dimana arsip dongeng Indonesia saat ini tidak dapat lagi lengkap dan utuh di TMII. Dari hasil observasi ini, penulis tidak dapat membuat langsung pemetaan jenis dongeng nusantara. Hal ini disebabkan ketidaklengkapan arsip dongeng yang ditemui oleh penulis sehingga langkah selanjutnya adalah penulis mencoba membuat pemodelan arsip dongeng nusantara dengan cara melakukan studi literatur terhadap 353 buah dongeng nusantara yang berasal dari 34 provinsi dari beberapa buku dongeng yang sudah dipublikasikan secara luas. Dari hasil studi literatur tersebut, penulis dapat melakukan pemetaan jenis dongeng nusantara.

\subsection{Pemetaan Jenis Dongeng Nusantara}

Dongeng di Indonesia atau lebih dikenal dengan dongeng nusantara merupakan warisan budaya tradisi lisan sejak jaman nenek moyang. Dongeng digunakan untuk mendidik sekaligus menghibur anak dalam keseharian mereka. Dalam penelitian ini, penulis berhasil mengumpulkan sebanyak 353 buah judul dongeng nusantara yang dibagi kedalam 34 provinsi di Indonesia. Temuan dalam studi literatur ini kemudian dipetakan berdasarkan jenis dongengnya. Dongeng Nusantara merupakan warisan budaya tradisi lisan sejak jaman nenek moyang yang bersifat mendidik sekaligus menghibur. Banyak sekali jenis dongeng yang ada, namun penulis membatasi kepada 6 jenis dongeng berdasarkan perbedaan antar jenisnya. Adapun Jenis-jenis dongeng nusantara yang dimaksud adalah: Legenda, Mitos, Fabel, Parabel, Sage dan Epos.

Penulis menentukan 6 jenis dongeng antara lain: Legenda, Mitos, Fabel, Parabel, Sage dan Epos. Keenam jenis ini pun menghasilkan beberapa jenis baru yang merupakan elaborasi antara 2 atau 3 jenis. Adapun hasil pemetaan berdasarkan jenis dongeng dibagi berdasarkan wilayah, antara lain: Sumatera, Jawa (termasuk Bali, Nusa Tenggara Barat dan Timur), Kalimantan, Sulawesi dan Papua (termasuk Maluku, Maluku Utara dan Papua Barat). 
Pembagian jenis ini berdasarkan ciri dongeng tersebut. Legenda merupakan jenis dongeng yang menceritakan terjadinya sebuah peristiwa dimana ada bukti artefaknya hingga saat ini. Mitos merupakan jenis dongeng yang menceritakan sesuatu bersifat magis atau religius dimana masyarakat masih mempercayainya. Fabel merupakan jenis dongeng dengan karakter utamanya adalah hewan yang memiliki sifat-sifat manusia. Parabel merupakan jenis dongeng yang kental berisi nilai-nilai Pendidikan. Sage merupakan jenis dongeng yang menceritakan peristiwa bersejarah. Epos merupakan jenis dongeng yang menceritakan tentang kepahlawanan dari tokoh di dalam cerita.

Hasil temuan penelitian terhadap pemetaan jenis dongeng nusantara adalah adanya jenis-jenis dongeng nusantara hasil elaborasi dari 2 jenis dongeng. Berdasarkan hal tersebut, peneliti mencoba merangkum ke dalam tabel dibawah ini:

Tabel 1. Persentase Jenis Dongeng Nusantara

[Sumber: Hasil Pemetaan dari Studi Literatur, 2019]

\begin{tabular}{|c|c|c|c|c|c|c|c|c|}
\hline \multirow[b]{2}{*}{ No. } & \multirow[b]{2}{*}{ Provinsi } & \multicolumn{7}{|c|}{ Jenis Dongeng Nusantara (dalam \%) } \\
\hline & & Legenda & Mitos & Fabel & Parabel & Sage & Epos & $\begin{array}{l}\text { Lain- } \\
\text { lain }\end{array}$ \\
\hline 1. & Aceh & 8 & 8 & 8 & 77 & 0 & 0 & 0 \\
\hline 2. & Sumatera Utara & 67 & 17 & 0 & 17 & 0 & 0 & 0 \\
\hline 3. & Sumatera Barat & 25 & 8 & 0 & 33 & 0 & 0 & 33 \\
\hline 4. & Sumatera Selatan & 0 & 17 & 0 & 50 & 17 & 8 & 8 \\
\hline 5. & Riau & 14 & 0 & 14 & 71 & 0 & 0 & 0 \\
\hline 6. & Kepulauan Riau & 50 & 0 & 25 & 0 & 25 & 0 & 0 \\
\hline 7. & Bengkulu & 14 & 15 & 7 & 42 & 8 & 0 & 15 \\
\hline 8. & Jambi & 33 & 22 & 0 & 11 & 22 & 0 & 11 \\
\hline 9. & Lampung & 0 & 8 & 8 & 38 & 31 & 15 & 0 \\
\hline 10. & Bangka Belitung & 33 & 0 & 0 & 44 & 0 & 11 & 11 \\
\hline 11. & Banten & 21 & 21 & 0 & 43 & 14 & 0 & 0 \\
\hline 12. & Jawa Barat & 0 & 10 & 0 & 50 & 0 & 0 & 40 \\
\hline 13. & DKI Jakarta & 40 & 0 & 0 & 10 & 30 & 0 & 20 \\
\hline 14. & Jawa Tengah & 0 & 0 & 0 & 45 & 9 & 0 & 45 \\
\hline 15. & Yogyakarta & 27 & 13 & 0 & 47 & 13 & 0 & 0 \\
\hline 16. & Jawa Timur & 6 & 6 & 6 & 67 & 0 & 0 & 17 \\
\hline 17. & Bali & 18 & 0 & 9 & 55 & 9 & 0 & 9 \\
\hline 18. & Nusa Tenggara Barat & 8 & 8 & 8 & 50 & 0 & 0 & 25 \\
\hline 19. & Nusa Tenggara Timur & 11 & 0 & 11 & 67 & 11 & 0 & 0 \\
\hline 20. & Kalimantan Barat & 55 & 9 & 18 & 9 & 9 & 0 & 0 \\
\hline 21. & Kalimantan Selatan & 29 & 21 & 0 & 36 & 7 & 7 & 0 \\
\hline 22. & Kalimantan Tengah & 25 & 8 & 0 & 58 & 0 & 0 & 9 \\
\hline 23. & Kalimantan Timur & 29 & 11 & 0 & 43 & 14 & 0 & 3 \\
\hline 24. & Kalimantan Utara & 0 & 14 & 0 & 14 & 29 & 14 & 28 \\
\hline 25. & Sulawesi Selatan & 0 & 0 & 7 & 85 & 0 & 7 & 0 \\
\hline 26. & Sulawesi Tenggara & 0 & 0 & 13 & 80 & 0 & 0 & 7 \\
\hline 27. & Sulawesi Tengah & 0 & 0 & 0 & 31 & 23 & 8 & 38 \\
\hline
\end{tabular}




\begin{tabular}{|c|l|c|c|c|c|c|c|c|}
\hline \multirow{2}{*}{ No. } & \multirow{2}{*}{ Provinsi } & \multicolumn{7}{|c|}{ Jenis Dongeng Nusantara (dalam \%) } \\
\cline { 3 - 9 } & & Legenda & Mitos & Fabel & Parabel & Sage & Epos & $\begin{array}{c}\text { Lain- } \\
\text { lain }\end{array}$ \\
\hline 28. & Sulawesi Utara & 23 & 0 & 0 & 78 & 0 & 0 & 0 \\
\hline 29. & Sulawesi Barat & 0 & 0 & 0 & 75 & 25 & 0 & 0 \\
\hline 30. & Gorontalo & 12 & 13 & 13 & 50 & 12 & 0 & 0 \\
\hline 31. & Maluku & 11 & 11 & 34 & 22 & 11 & 0 & 11 \\
\hline 32. & Maluku Utara & 20 & 0 & 20 & 40 & 0 & 0 & 20 \\
\hline 33. & Papua & 0 & 11 & 11 & 78 & 0 & 0 & 0 \\
\hline 34. & Papua Barat & 25 & 0 & 0 & 25 & 0 & 0 & 50 \\
\hline
\end{tabular}

Adanya jenis dongeng nusantara hasil elaborasi 2 jenis dongeng sebelumnya merupakan temuan penelitian yang didapat ketika penulis mendata dan memetakan jenis-jenis dongeng berdasarkan studi literatur dari 353 buah judul dongeng Nusantara dari 34 provinsi di Indonesia. Hasil elaborasi tersebut masuk ke dalam tabel lain-lain, yang selanjutnya diperjelas pada bentuk infografisnya.

\subsection{Pemetaan dan Infografis Jenis Dongeng Sumatera}

Penulis melakukan kajian terhadap 13 buah dongeng Aceh berjudul: O Ibu, O Padi Muda, Pangeran Amat Mude, Keluarga si Kepar, Air Mata Puteri Pukes, Atu Belah, Inen Maskerning, Kisah Putri Pucuk Gelumpang, Putri Hijau dan Sultan Mukhayat, Mentiko Betuah, Legenda Labuhan Haji, Banta Seudang, Panglima Sekunca, Merah Mege. Dari ketiga belas dongeng yang dikaji, penulis memetakan ke dalam 4 jenis dongeng yaitu: Legenda, Mitos, Fabel dan Parabel. Simpulan pemetaan jenis dongeng Aceh adalah 10 buah dongeng jenis Parabel atau sebesar $77 \%$, sedangkan jenis Legenda, Mitos dan Fabel masing-masing 1 buah atau sebesar $8 \%$.

Penulis melakukan kajian terhadap 12 buah dongeng Sumatera Utara yang berjudul: Legenda Pohon Enau, Pulau si Kantan, Asal Usul Danau Toba, Batu Gantung di Kota Parapat, Danau Kawar di Tanah Karo, Danau si Losung dan si Pinggan, Legenda Sampuraga, Puti Hijau Meriam dan Naga, Hidung Putri Simalungun, Benih Padi Putri Buruti Siraso, Putri Tapi Raja Uasan dan Pohon Sakti Si Beru Dayang. Dari Keduabelas dongeng tersebut, penulis kemudian memetakan ke dalam 3 jenis dongeng yaitu: Legenda, Mitos dan Parabel. Simpulan pemetaan jenis dongeng Sumatera Utara adalah sebanyak 8 buah dongeng jenis Legenda atau sebesar 67\%. Sedangkan jeni Mitos dan Parabel masing-masing 2 buah atau sebesar $17 \%$.

Penulis melakukan kajian terhadap 12 buah dongeng Sumatera Barat yang berjudul: Siamang Putih, Si Lebai yang Malang, Malin Kundang, Sumpah Putri Melur, Asal Mula Nagari Minangkabau, Kisah Bunda Kanduang, Legenda Danau Maninjau, Legenda Danau Singkarak dan Sungai Batang Ombilin, Kisah di Lembah Harau, Mak Isun Kayo, Legenda Batu Ajuang Batu Peti, Kisah Cinta Anggun nan Tongga. Dari kedua belas dongeng tersebut, penulis memetakan dongeng Sumatera Barat ke dalam 3 jenis yaitu: Legenda, Sage dan Parabel. Selain ketiga jenis dongeng tersebut, terdapat irisan antar jenis dongeng seperti: Legenda Parabel, Legenda Sage dan Mitos Parabel. Simpulan 
pemetaan jenis dongeng Sumatera Barat adalah 4 buah dongeng jenis Parabel atau sebesar 33\%, 3 buah dongeng jenis Legenda atau sebesar 25\% dan 2 buah dongeng jenis Legenda Parabel atau sebesar 17\%. Jenis Sage, Legenda Parabel dan Mitos Parabel masing-masing 1 buah cerita atau sebesar $8 \%$.
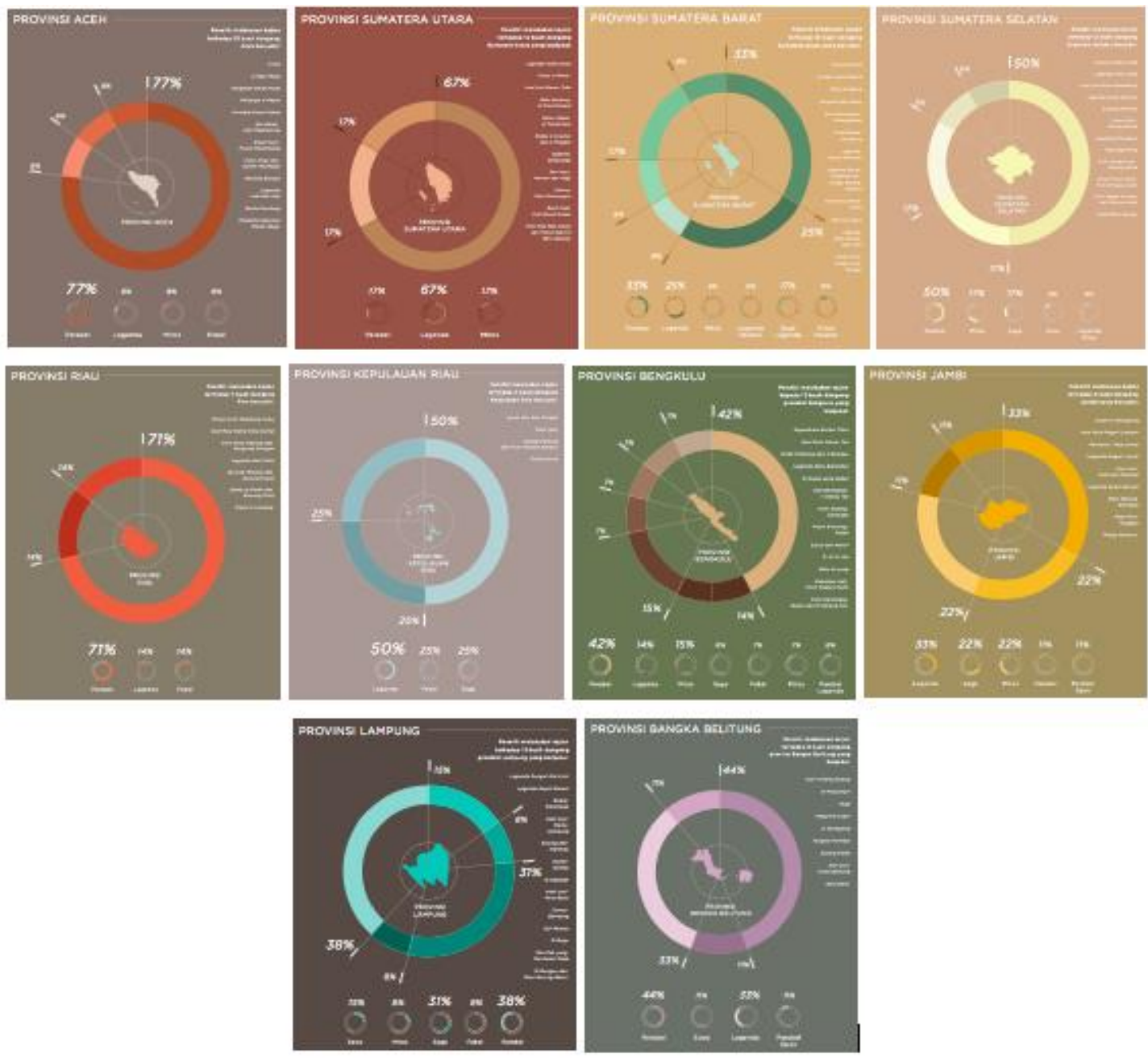

Gambar 3. Infografis Pemetaan Jenis Dongeng 10 Provinsi di Pulau Sumatera [Sumber: Dokumentasi Penulis, 2019]

Penulis melakukan kajian terhadap 12 buah dongeng Sumatera Selatan yang berjudul: Kisah si Pahit Lidah, Legenda Antu Ayek, Asal Usul Kota Palembang, Legenda Pulau Kemaro, Dayang Merindu, Kisah Putri Pinang Masak, Legenda Silangpari, Ting Gegenting, Putri Bungsu dan Bujang Katak, Jeruk Purut untuk Putri Bongsu Alam, Putri Bagus Kuning dan Siluman Kera, Kisah Ratu Agung. Dari keduabelas dongeng tersebut, penulis memetakan dongeng provinsi Sumatera Selatan ke dalam 4 jenis yaitu: Mitos, Parabel, Sage dan Epos. Selain keempat jenis dongeng tersebut, terdapat sebuah irisan antar jenis dongeng yakni Legenda Mitos. Simpulan pemetaan jenis dongeng provinsi Sumatera Selatan adalah 6 buah dongeng jenis Parabel atau sebesar 50\%, 2 buah dongeng jenis Mitos dan Sage atau sebesar 17\% dan 1 buah dongeng jenis Epos dan Legenda Mitos atau sebesar $8 \%$. 
Penulis melakukan kajian terhadap 7 buah dongeng Riau yang berjudul: Tarian Putri Mambang Linau, Asal Mula Nama Kota Dumai, Putri Kaca Mayang dan Panglima Gimpam, Legenda Ikan Patin, Burung Tempua dan Burung Puyuh, Bawang Merah dan Bawang Putih, Kisah si Lancang. Dari ketujuh dongeng provinsi Riau, penulis memetakan ke dalam 3 jenis dongeng yaitu: Legenda, Fabel dan Parabel. Simpulan dongeng provinsi Riau adalah 5 buah dongeng jenis Parabel atau sebesar 72\% sedangkan jenis Legenda dan Fabel masing-masing 1 buah atau sebesar $14 \%$.

Penulis melakukan kajian kepada 4 buah dongeng provinsi Kepulauan Riau berjudul: Ayam dan Ikan Tongko, Selat Nasi, Jenang Perkasa dan Putri Pandan Berduri, Pulau Senua. Dari keempat dongeng provinsi Kepulauan Riau, penulis ke dalam 3 jenis dongeng yaitu: Legenda, Fabel dan Sage. Simpulan pemetaan jenis dongeng provinsi Kepulauan Riau adalah sebanyak 2 buah dongeng jenis Parabel atau sebesar 50\% sedangkan jenis Fabel dan Sage masing-masing 1 buah atau sebesar $25 \%$.

Penulis melakukan kajian kepada 13 buah dongeng provinsi Bengkulu yang berjudul: Sayembara Pantai Tidur, Asal Mula Danau Tes, Kisah N’Daung dan si Bungsu, Legenda Batu Berambai, Si Gulap yang Sabar, Ular Berkepala 7 Danau Tes, Putri Gading Cempaka, Kisah Sinatung Natak, Siput dan Kancil, Putri Sulita, Batu Kuyung, Kebaikan Hati Putri Sedaro Putih, Putri Serindang Bulan dan Ki Karang Nio. Dari ketiga belas dongeng provinsi Bengkulu, penulis memetakan ke dalam 6 jenis dongeng yaitu: Legenda, Mitos, Fabel, Parabel, Sage dan Epos. Selain keenam jenis dongeng tersebut, terdapat sebuah irisan antar jenis dongeng yakni Legenda Parabel. Simpulan pemetaan dongeng provinsi Bengkulu adalah sebanyak 6 buah dongeng jenis Parabel atau sebesar 43\%, jenis Legenda sebanyak 2 buah atau sebesar 14\%. Sedangkan jenis lainnya seperti: Mitos, Fabel, Sage, Epos dan Legenda Parabel masing-masing 1 buah dongeng atau sebesar 7\%

Penulis melakukan kajian terhadap 9 buah dongeng Jambi yang berjudul: Kisah si Kelingking, Asal Mula Negeri Lempur, Pencarian Raja Jambi, Legenda Negeri Jambi, Asal Usul Kuburan Keramat, Legenda Bukit Kancah, Batu Betung Bertakuk, Padi Putri Tangguk, Telaga Beracun. Dari kesembilan dongeng di atas, penulis memetakan dongeng provinsi Jambi kedalam 4 jenis yaitu: Legenda, Mitos, Parabel dan Sage. Selain keempat jenis tersebut, terdapat sebuah irisan antar jenis dongeng yakni Parabel Epos. Simpulan pemetaan dongeng provinsi Jambi adalah sebanyak 3 buah dongeng jenis Legenda atau sebesar 34\%, jenis Sage dan Mitos masing-masing sebanyak 2 buah atau sebesar 22\%. Jenis Parabel dan Parabel Epos masing-masing 1 buah atau sebesar $11 \%$.

Penulis melakukan kajian terhadap 13 buah dongeng provinsi Lampung yang berjudul: Legenda Sungai Wai Linti, Legenda Gajah Meram, Buaya Perompak, Asal Usul Nama Lampung, Kucing dan Harimau, Sultan Domas, Si Kabelah, Asal Usul Kota Bumi, Sumur Bandung, Dul Remos, Si Bugu, Telu Pak yang Tak Kalah Telak, Si Bungsu dan Telur Burung Kenui. Dari ketiga belas dongeng tersebut, penulis memetakan dongeng provinsi Lampung ke dalam 5 jenis dongeng yaitu: Mitos, Fabel, Parabel, Sage dan Epos. Simpulan pemetaan dongeng provinsi Lampung adalah sebanyak 5 buah dongeng jenis Parabel atau sebesar 38\%, jenis Sage sebanyak 4 buah atau sebesar 31\%, jenis Epos sebanyak 2 
buah atau sebesar 15\%. Sedangkan jenis Mitos dan Fabel masing-masing sebanyak 1 buah atau sebesar $8 \%$.

Penulis melakukan kajian terhadap 9 buah dongeng provinsi Bangka Belitung yang berjudul: Putri Pinang Gading, Si Penyumpit, Paga, Panglima Angin, Si Kelingking, Tongkat Permata, Bujang Katak, Asal Usul Pulau Belitung, Batu Balai. Dari kesembilan dongeng tersebut, penulis memetakan dongeng provinsi Bangka Belitung ke dalam 3 jenis dongeng yaitu: Legenda, Parabel dan Epos. Selain ketiga jenis dongeng tersebut, ada sebuah irisan antar jenis dongeng yakni Parabel Epos. Simpulan pemetaan dongeng provinsi Bangka Belitung adalah sebanyak 4 buah dongeng jenis Parabel atau sebesar $45 \%$, jenis Legenda sebanyak 3 buah atau sebesar 33\%. Sedangkan jenis Epos dan Parabel Epos masing-masing sebanyak 1 buah atau sebesar $11 \%$.

\subsection{Pemetaan dan Infografis Jenis Dongeng Jawa, Bali, NTB dan NTT}

Penulis melakukan kajian kepada 14 buah dongeng provinsi Banten yang berjudul: Asal Mula Rawadanau, Legenda Tanjung Lesung, Legenda Cika Putrian, Raksasa Puncak Aseupan, Tuah Kutuk Aki Monggor, Si Batu, Legenda Prasasti Munjul, Pangeran Pande Gelang dan Putri Candasari, Telaga Warna, Batu Kuwung, Legenda Sumur Tujuh, Riwayat Masjid Sumpah Terate, Asal Usul Gunung Pinang, Nini Plerek si Penyihir Jahat. Dari keempat belas dongeng provinsi Banten, penulis memetakan ke dalam 4 jenis dongeng yaitu: Legenda, Mitos, Parabel dan Sage. Simpulan pemetaan jenis dongeng provinsi Banten adalah sebanyak 6 buah dongeng jenis Parabel atau sebesar $43 \%$, jenis Legenda dan Mitos masing-masing sebanyak 3 buah atau sebesar $22 \%$, dan jenis Sage sebanyak 2 buah atau sebesar $14 \%$.

Penulis melakukan kajian terhadap 10 buah dongeng provinsi DKI Jakarta yang berjudul: Si Pitung, Kisah Nyai Dasima, Si Jampang, Misteri Si Manis Jembatan Ancol, Murtado Jagoan dari Kemayoran, Angkri Preman Pasar Ikan, Si Panjang, Entong Gendut, Misteri Kampung Pecah Kulit, Mirah Singa Betina dari Marunda. Dari kesepuluh dongeng di atas, penulis memetakan dongeng provinsi DKI Jakarta ke dalam 2 jenis dongeng yaitu: Mitos dan Parabel. Selain kedua jenis dongeng tersebut, terdapat sebuah irisan antar jenis dongeng yakni Sage Epos. Simpulan dari pemetaan jenis dongeng provinsi DKI Jakarta adalah sebanyak 5 buah dongeng jenis Sage Epos atau sebesar 50\%, jenis Parabel sebanyak 4 buah atau sebesar $40 \%$ dan jenis Mitos sebanyak 1 buah atau sebesar $10 \%$.

Penulis melakukan kajian terhadap 10 buah dongeng provinsi Jawa Barat yang berjudul: Mundinglaya Dikusumah, Legenda Tangkuban Perahu, Lutung Kasarung, Asal Usul Ciganjur, Asal Usul Telaga Warna, Riwayat Nama Cirebon, Karang Nini di Pangandaran, Legenda Situ Bagendit, Riwayat Nama Desa Watu Belah, Nyi Mas Gandasari. Dari kesepuluh dongeng provinsi Jawa Barat, penulis memetakan ke dalam 3 jenis dongeng yaitu: Legenda, Parabel dan Sage. Selain ketiga jenis dongeng tersebut, ada 2 buah irisan antar jenis dongeng yakni Parabel Sage dan Parabel Epos. Simpulan pemetaan dongeng provinsi Jawa Barat adalah sebanyak 4 buah dongeng jenis Legenda atau sebesar $40 \%$, jenis Sage sebanyak 3 buah atau sebesar 30\%, sedangkan jenis Parabel, Parabel Sage dan Parabel Epos masing-masing sebanyak 1 buah atau sebesar 10\%. 
Penulis melakukan kajian kepada 11 buah dongeng provinsi Jawa Tengah yang berjudul: Timun Mas, Bawang Merah dan Bawang Putih, Joko Bodo, Kisah Cinta Roro Mendut, Asal Usul Candi Borobudur, Jaka Tingkir, Riwayat Kota Salatiga, Joko Kendil, Legenda Rawa Pening, Roro Jonggrang, Cindelaras. Dari kesebelas dongeng provinsi Jawa Tengah, penulis memetakan ke dalam 2 jenis dongeng yaitu: Parabel dan Sage. Selain kedua jenis tersebut, ada 2 irisan antar jenis dongeng yakni Legenda Mitos dan Legenda Sage. Simpulan pemetaan jenis dongeng provinsi Jawa Tengah adalah sebanyak 5 buah dongeng jenis Parabel atau sebesar 46\%, jenis Sage sebanyak 4 buah atau sebesar $36 \%$, sedangkan jenis Legenda Mitos dan Legenda Sage masing-masing sebanyak 1 buah atau sebesar $9 \%$.
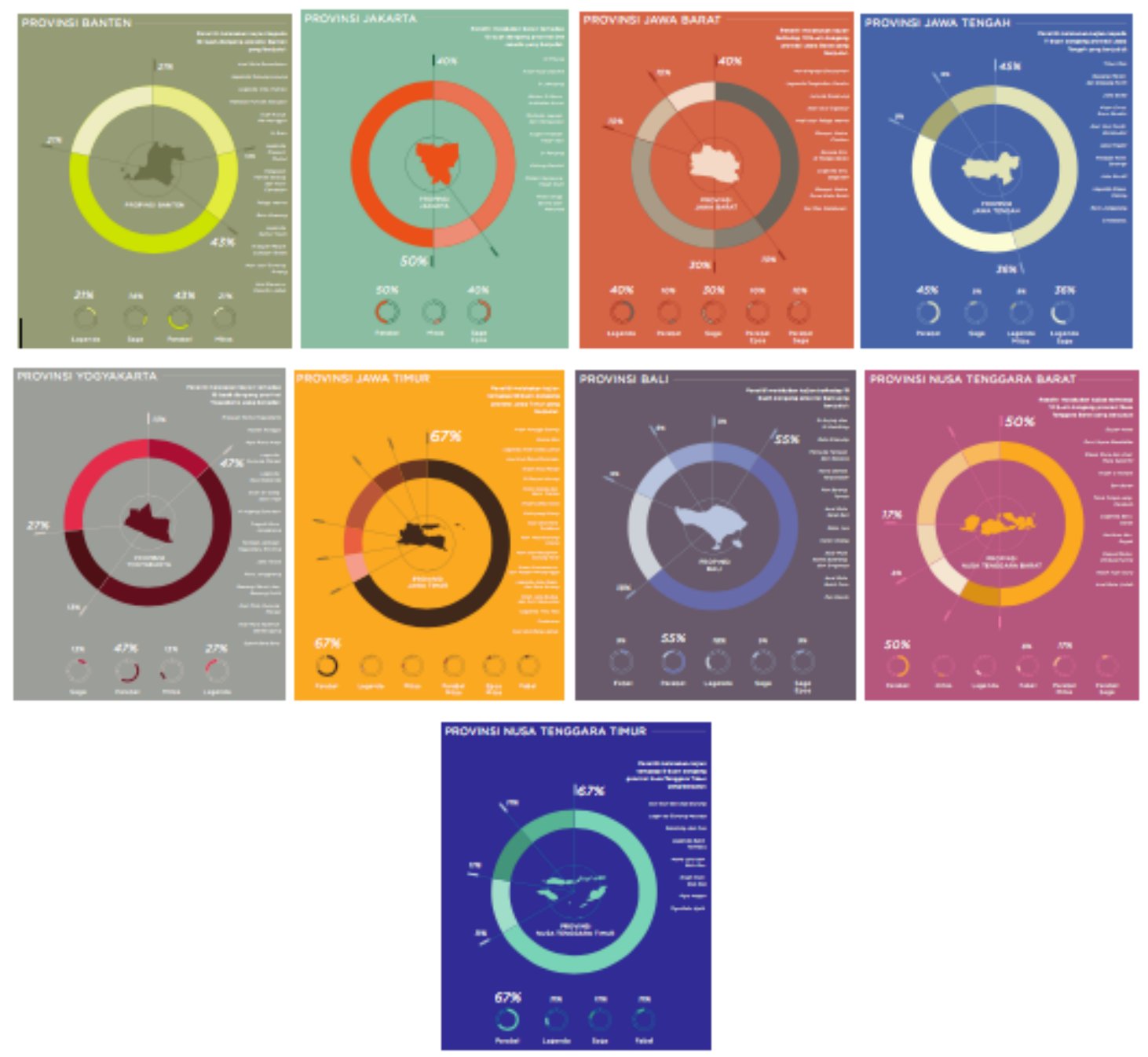

Gambar 4. Infografis Pemetaan Jenis Dongeng 9 Provinsi di Pulau Jawa, Bali, NTB dan NTT [Sumber: Dokumentasi Penulis, 2019]

Penulis melakukan kajian terhadap 15 buah dongeng provinsi Yogyakarta yang berjudul: Riwayat Nama Yogyakarta, Raden Ronggo, Nyai Roro Kidul, Legenda Gunung Merapi, Legenda Goa Kiskerida, Dewi Sri Sang Dewi Padi, Ki Ageng Sukowati, Tragedi Roro Jonggrang, Tombak Jelmaan Naga Baru Klinting, Jaka Tarub, Roro Jonggrang, Bawang Merah dan Bawang Putih, Asal Mula Gunung Merapi, Asal Mula Nyamuk Berdengung, 
Syekh Bela Belu. Dari kelima belas dongeng provinsi Yogyakarta, penulis memetakan ke dalam 4 jenis dongeng yaitu: Legenda, Mitos, Parabel dan Sage. Simpulan pemetaan jenis dongeng provinsi Yogyakarta adalah sebanyak 7 buah dongeng jenis Parabel atau sebesar $47 \%$, jenis Legenda sebanyak 4 buah atau sebesar $27 \%$, sedangkan jenis Legenda Mitos dan Sage masing-masing sebanyak 2 buah atau sebesar $13 \%$.

Penulis melakukan kajian terhadap 18 buah dongeng provinsi Jawa Timur yang berjudul: Kisah Rangga Gading, Keong Mas, Legenda Ande-ande Lumut, Asal Usul Reog Ponorogo, Kisah Arya Menak, Si Penjual Kucing, Colon Arang dan Keris Weling, Kisah Lembu Sura, Kota yang Hilang, Asal Usul Kota Surabaya, Asal Mula Gunung Arjuna, Asal Usul Pasugihan Gunung Kawi, Prabu Damarwulan dan Adipati Minakjingga, Legenda Jaka Seger dan Rara Anteng, Kisah Jaka Budug dan Putri Kemuning, Legenda Timun Mas, Cindelaras, Asal Usul Banyuwangi. Dari kedelapan belas dongeng provinsi Jawa Timur, penulis memetakan ke dalam 4 jenis dongeng yaitu: Legenda, Mitos, Fabel dan Parabel. Selain keempat jenis dongeng tersebut, ada 2 irisan antar jenis dongeng yakni Mitos Parabel dan Mitos Epos. Simpulan pemetaan jenis dongeng provinsi Jawa Timur adalah sebanyak 12 buah dongeng jenis Parabel atau sebesar 67\%, jenis Mitos Parabel sebanyak 2 buah atau sebesar 11\%, sedangkan jenis Legenda, Mitos, Fabel dan Mitos Epos masingmasing sebanyak 1 buah atau sebesar $6 \%$.

Penulis melakukan kajian terhadap 11 buah dongeng provinsi Bali yang berjudul: Si Anjing dan Si Kambing, Batu Kawung, Pemuda Tampan dari Dewata, Harta Benda Terpendam, Pan Balang Tamak, Asal Mula Selat Bali, Kebo Iwa, Calon Arang, Asal Mula Nama Buleleng dan Singaraja. Asal Mula Bukit Catu, Pan Kasim. Dari kesebelas dongeng provinsi Bali, penulis memetakan ke dalam 4 jenis dongeng yaitu: Legenda, Fabel, Parabel dan Sage. Selain keempat jenis tersebut ada sebuah irisan jenis dongeng yakni Sage Epos. Simpulan pemetaan dongeng provinsi Bali adalah sebanyak 6 buah dongeng jenis Parabel atau sebesar 55\%, sedangkan jenis Fabel, Sage dan Sage Epos masingmasing sebanyak 1 buah atau sebesar $9 \%$.

Penulis melakukan kajian terhadap 12 buah dongeng provinsi Nusa Tenggara Barat yang berjudul: Doyan Nada, Putri Nyale Mandalika, Wewe Wula dan Asal Mula Suka Nil, Kisah si Pondik, Sari Bulan, Tong Tonge yang Ceroboh, Legenda Batu Golok, Harimau dan Gagak, Papuq Mame Embuq Puntiq, Kisah Tuan Guru, Asal Mula Lintah. Dari kedua belas dongeng provinsi Nusa Tenggara Barat, penulis memetakan ke dalam 4 jenis dongeng yaitu: Legenda, Mitos, Fabel dan Parabel. Selain keempat jenis dongeng tersebut, ada 2 irisan antar jenis dongeng yakni Mitos Parabel dan Parabel Sage. Simpulan pemetaan dongeng provinsi Nusa Tenggara Barat adalah sebanyak 6 buah dongeng jenis Parabel atau sebesar $50 \%$, jenis Mitos Parabel sebanyak 2 buah atau sebesar $17 \%$, sedangkan jenis Legenda, Mitos, Fabel dan Parabel Sage masing-masing sebanyak 1 buah atau sebesar $8 \%$.

Penulis melakukan kajian terhadap 9 buah dongeng provinsi Nusa Tenggara Timur yang berjudul: Suri Ikun dan Dua Burung, Legenda Gunung Mauraja, Sekolong dan Cue, Legenda Bukit Fafinesu, Mane Loro dan Bete Dou, Kisah Putri Bue Gae, Pipit Medah, Tiga 
Batu Ajaib. Dari kesembilan dongeng provinsi Nusa Tenggara Timur, penulis memetakan ke dalam 4 jenis dongeng yaitu: Legenda, Fabel, Parabel dan Sage. Simpulan pemetaan dongeng provinsi Nusa Tenggara Timur adalah sebanyak 6 buah dongeng jenis Parabel atau sebesar $67 \%$, sedangkan jenis Legenda, Fabel dan Sage masing-masing sebanyak 1 buah atau sebesar $11 \%$.

\subsection{Pemetaan dan Infografis Jenis Dongeng Kalimantan}

Penulis melakukan kajian terhadap 11 buah dongeng provinsi Kalimantan Barat yang berjudul: Batu Menangis, Semangka Emas dan Lumpur, Legenda Sungai Landak, Asal Usul Bukit Kelam, Legenda Pulau Belumbak, Goa Lawangkuwari, Kancil yang Cerdik, Legenda Burung Ruwai, Bujang Beji, Sungai Kawat, Persahabatan Ikan Gabus dan Tupai. Dari kesebelas dongeng provinsi Kalimantan Barat, penulis memetakan ke dalam 5 jenis dongeng yaitu: Legenda, Mitos, Fabel, Parabel dan Sage. Simpulan pemetaan dongeng provinsi Kalimantan Barat adalah sebanyak 6 buah dongeng jenis Legenda atau sebesar $55 \%$, jenis Fabel sebanyak 2 buah atau sebesar 18\%, sedangkan jenis Mitos, Parabel dan Sage masing-masing sebanyak 1 buah atau sebesar $9 \%$.
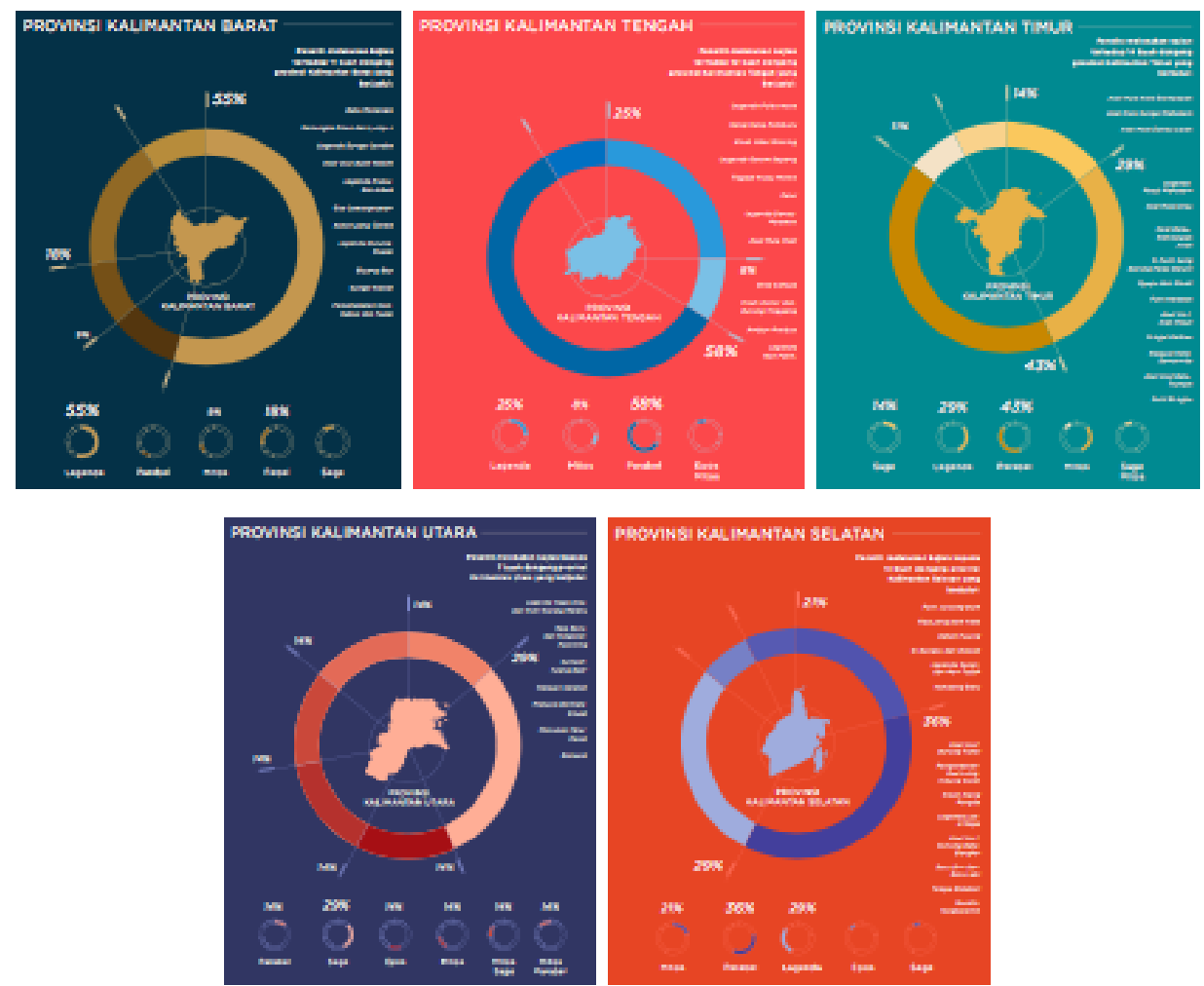

Gambar 5. Infografis Pemetaan Jenis Dongeng 5 Provinsi di Pulau Kalimantan [Sumber: Dokumentasi Penulis, 2019]

Penulis melakukan kajian terhadap 12 buah dongeng provinsi Kalimantan Tengah yang berjudul: Legenda Pulau Nusa, Sangi Sang Pemburu, Kisah Uder Mincing, Legenda Garam Sepang, Tragedi Pulau Mintin, Palui, Legenda Danau Malawen, Asal Mula Padi, Bilip Sahaya, Kisah Dohor dan Burung Tinggang, Ambun Rimbun, Legenda Ikan Patin. Dari keduabelas dongeng provinsi Kalimantan Tengah, penulis memetakan ke dalam 3 jenis 
dongeng yaitu: Legenda, Mitos dan Parabel. Selain ketiga jenis dongeng tersebut, ada sebuah irisan antar jenis dongeng yakni Mitos Epos. Simpulan pemetaan dongeng provinsi Kalimantan Tengah adalah sebanyak 7 buah dongeng jenis Parabel atau sebesar $59 \%$, jenis Legenda sebanyak 3 buah atau sebesar 25\%, sedangkan jenis Mitos dan Mitos Epos masing-masing sebanyak 1 buah atau sebesar $8 \%$.

Penulis melakukan kajian terhadap 14 buah dongeng provinsi Kalimantan Timur yang berjudul: Asal Mula Kota Balikpapan, Asal Mula Sungai Mahakam, Asal Mula Danau Lipan, Legenda Pesut Mahakam, Asal Mula Erau, Nyai Balau Kehilangan Anak, Si Putri Sang Burung Palas Baruni, Nyapu dan Moret, Putri Kelawot, Asal Usul Ikan Pesut, Sungai Kerbau, Riwayat Kota Samarinda, Asal Usul Batu Trumpit, Putri Bungsu. Dari keempat belas dongeng provinsi Kalimantan Timur, penulis memetakan ke dalam 4 jenis dongeng yaitu: Legenda, Mitos, Parabel dan Sage. Selain keempat dongeng tersebut, ada sebuah irisan antar dongeng yakni Mitos Sage. Simpulan pemetaan dongeng provinsi Kalimantan Timur adalah sebanyak 6 buah dongeng jenis Parabel atau sebesar $43 \%$, jenis Legenda sebanyak 4 buah atau sebesar 29\%, jenis Sage sebanyak 2 buah atau sebesar 14\%. Sedangkan jenis Mitos dan Mitos Sage masing-masing sebanyak 1 buah atau sebesar $7 \%$.

Penulis melakukan kajian kepada 7 buah dongeng provinsi Kalimantan Utara yang berjudul: Legenda Naga Erau dan Putri Karang Melenu, Raja Bunu dan Pangeran Paninting, Sumpah Tulang Badi', Nelayan Serakah, Manusia Bermata Empat, Monumen Telur Pecah, Benayuk. Dari ketujuh dongeng provinsi Kalimantan Utara, penulis memetakan ke dalam 4 jenis dongeng yaitu: Mitos, Parabel, Sage dan Epos. Selain keempat jenis dogneng tersebut, ada 2 irisan antar jenis dongeng yakni Mitos Parabel dan Mitos Sage. Simpulan pemetaan dongeng provinsi Kalimantan Utara adalah sebanyak 2 buah dongeng jenis Sage atau sebesar 29\%, sedangkan jenis Mitos, Parabel, Epos dan Mitos Epos masing-masing sebanyak 1 buah atau sebesar 14\%.

Penulis melakukan kajian kepada 14 buah dongeng provinsi Kalimantan Selatan yang berjudul: Putri Junjung Buih, Raja yang baik Hate, Datuk Pujung, Si Bungsu dan Biawak, Legenda Sajian dan Ikan Todak, Hampang Batu, Asal Usul Burung Punai, Pengorbanan Dwi Luing Indung Bulan, Kisah Niang Rangda, Legenda Lok si Naga, Asal Usul Gunung Batu Bangkai, Batu Bini dan Batu Laki, Telaga Bidadari, Mandin Tangkaramin. Dari keempat belas dongeng provinsi Kalimantan Selatan, penulis memetakan ke dalam 5 jenis dongeng yaitu: Legenda, Mitos, Parabel, Sage dan Epos. Simpulan pemetaan dongeng provinsi Kalimantan Selatan adalah sebanyak 5 buah dongeng jenis Parabel atau sebesar 36\%, jenis Legenda sebanyak 4 buah atau sebesar $29 \%$, jenis Mitos sebanyak 3 buah atau sebesar 21\%. Sedangkan jenis Sage dan Epos masing-masing sebanyak 1 buah atau sebesar $7 \%$.

\subsection{Pemetaan Jenis Dongeng Sulawesi}

Penulis melakukan kajian kepada 9 buah dongeng provinsi Sulawesi Utara yang berjudul: Lengkebong si Pemalas, Dongeng Burung Moopo, Asal Usul Danau Tandano, Abo Mamongkuroit dan Raksasa, Legenda PUlau Napombalu, Kisah Wuwung Sewe dan 
Buaya, Kisah Burung Kekekow, Sigar Laki dan Limbat, Ratu Adioa yang Budiman. Dari kesembilan dongeng provinsi Sulawesi Utara, penulis memetakan ke dalam 2 jenis dongeng yaitu: Legenda dan Parabel. Simpulan pemetaan dongeng provinsi Sulawesi Utara adalah sebanyak 7 buah dongeng jenis Parabel atau sebesar $78 \%$, sedangkan jenis Legenda sebanyak 2 buah atau sebesar $22 \%$.
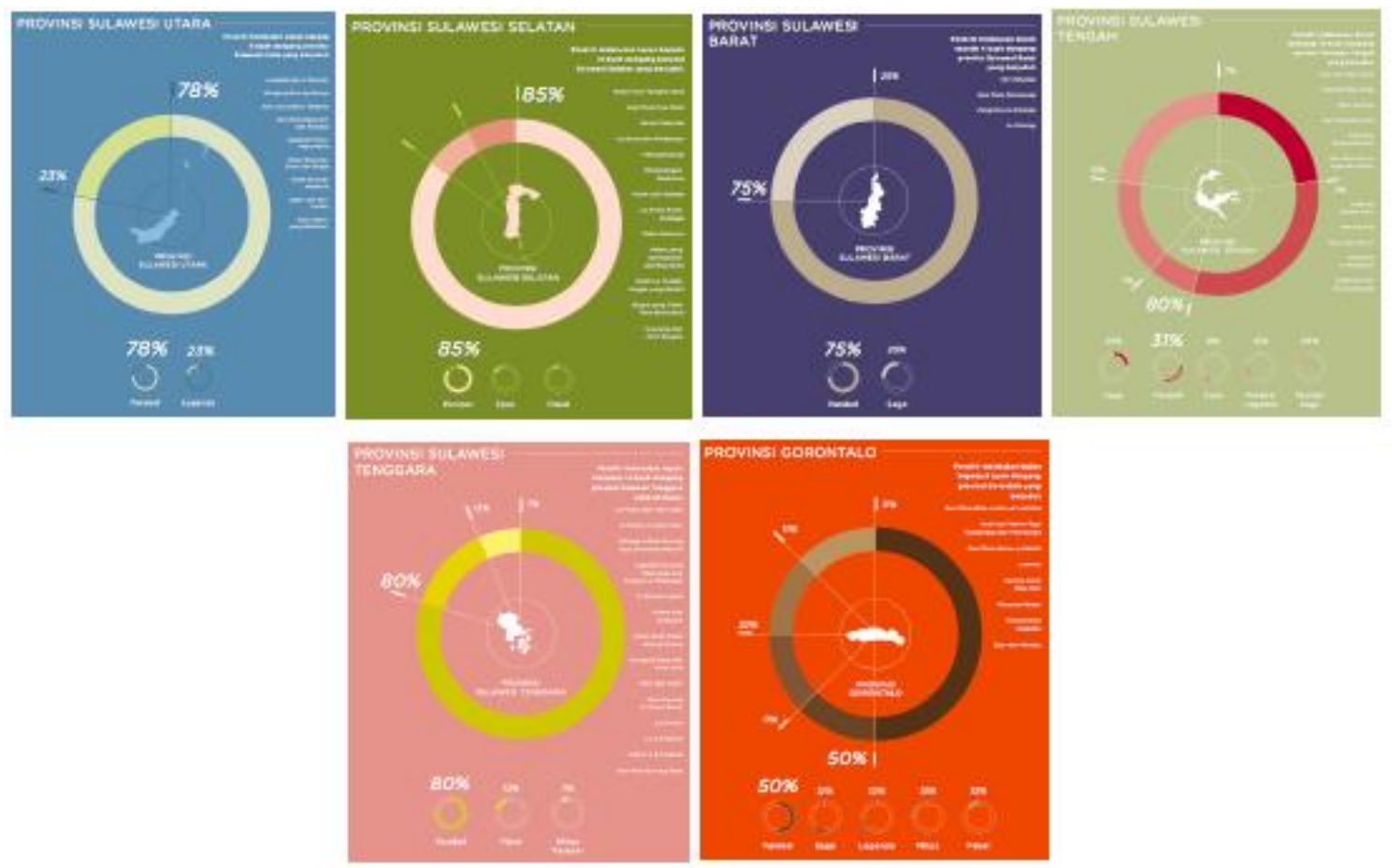

Gambar 6. Infografis Pemetaan Jenis Dongeng 6 Provinsi di Pulau Sulawesi

[Sumber: Dokumentasi Penulis, 2019]

Penulis melakukan kajian kepada 13 buah dongeng provinsi Sulawesi Selatan yang berjudul: Kisah Putri Tandam Palik, Asal Mula Pula Wajo, Nenek Pakande, La Dana dan Kerbaunya, I Manyambungi, Pertandingan Berbicara, Kisah Laki Padada, La Kuttu Kuttu Paddaga, La Kuttu Kuttu Paddaga dan Gadis Penenun, Kakek yang beristerikan seorang Gadis, Kisah La Tongko tongko yang Bodoh, Buaya yang Tidak Tahu Balas Budi, I Laurang dan Putri Bungsu. Dari ketiga belas dongeng provinsi Sulawesi Selatan, penulis memetakan ke dalam 3 jenis dongeng yaitu: Fabel, Parabel dan Epos. Simpulan pemetaan jenis dongeng provini Sulawesi Selatan adalah sebanyak 11 buah dongeng jenis Parabel atau sebesar 84\%, sedangkan jenis Fabel dan Epos masing-masing sebanyak 1 buah atau sebesar $8 \%$.

Penulis melakukan kajian kepada 4 buah dongeng provinsi Sulawesi Barat yang berjudul: Tari Patuddu, Asal Mula Pamboang, Panglima to Dilalang, to Dilaling. Dari keempat dongeng provinsi Sulawesi Barat, penulis memetakan ke dalam 2 jenis dongeng yaitu: Parabel dan Sage. Simpulan pemetaan jenis dongeng provinsi Sulawesi Barat adalah sebanyak 3 buah dongeng jenis Parabel atau sebesar 75\%, sedangkan jenis Sage sebanyak 1 buah atau sebesar $25 \%$. 
Penulis melakukan kajian terhadap 12 buah dongeng provinsi Sulawesi Tengah yang berjudul: Asal Usul Raja Taura, Legenda Batu Baga, Datu Pamona, Tau Niulaya Nu Bau, Asal Mula Kampung Payol, Asal Mula Pohon Sagu dan Palem, Legenda Tanduk Alam, Ikan Duyung, Tadu Lako Bu Lili, Sesentola si Pemberani, Sesentola dan Burung Garuda. Dari kedua belas dongeng Sulawesi Tengah, penulis memetakan ke dalam 3 jenis dongeng yaitu: Parabel, Sage dan Epos. Selain ketiga jenis dongeng tersebut, ada 2 irisan jenis dongeng yakni Legenda Parabel dan Parabel Sage. Simpulan pemetaan jenis dongeng provinsi Sulawesi Tengah adalah sebanyak 4 buah dongeng jenis Parabel atau sebesar 31\%, jenis Sage dan Parabel Sage masing-masing sebanyak 3 buah atau sebesar 23\%, jenis Legenda Parabel sebanyak 2 buah atau sebesar 15\%, sedangkan jenis Epos sebanyak 1 buah atau sebesar $8 \%$.

Penulis melakukan kajian terhadap 14 buah dongeng provinsi Sulawesi Tenggara yang berjudul: La Moelu dan Ikan Ajaib, La Moelu si Anak Piatu, Mengapa Dada Burung Pipit Berwarna Merah?, Legenda Gunung Mekongga dan Sungai La Mekongga, Si KEmbar Ajaib, Indara dan Siraapare, Kisah Anak Gadis Niining Kubea, Dongeng Rusa dan Kurakura, Kera dan Ayam, Ikan Duyung di Tanah Buton, La Ontolu, La Sirimbone, Kisah La Sirimbone, Asal Mula Gunung Saba. Dari keempat belas dongeng provinsi Sulawesi Tenggara, penulis memetakan ke dalam 2 jenis dongeng yaitu: Fabel dan Parabel. Selain kedua jenis tersebut, ada sebuah irisan jenis dongeng yakni Mitos Parabel. Simpulan pemetaan dongeng provinsi Sulawesi Tenggara adalah sebanyak 12 buah dongeng jenis Parabel atau sebesar 80\%, jenis Fabel sebanyak 2 buah atau sebesar 13\%, sedangkan jenis Mitos Parabel sebanyak 1 buah atau sebesar $7 \%$.

Penulis melakukan kajian kepada 8 buah dongeng provinsi Gorontalo yang berjudul: Asal Mula Botu Liodu Lei Lahilote, Asal Usul Nama Tapa Tuladenggi dan Panthungo, Asal Mula Danau Limboto, Limonu, Mantra Ajaib Raja Ikan, Manusia Ketam, Penyamaran Labeddu, Sapi dan Kerbau. Dari kedelapan dongeng provinsi Gorontalo, penulis memetakan ke dalam 5 jenis dongeng yaitu: Legenda, Mitos, Fabel, Parabel dan Sage. Simpulan pemetaan jenis dongeng provinsi Gorontoalo adalah sebanyak 4 buah dongeng jenis Parabel atau sebesar 50\%, sedangkan jenis Legenda, Mitos, Fabel dan Sage masingmasing sebanyak 1 buah atau sebesar $12 \%$.

\subsection{Pemetaan Jenis Dongeng Maluku, Maluku Utara, Papua dan Papua Barat}

Penulis melakukan kajian kepada 9 buah dongeng provinsi Maluku yang berjudul: Buaya Tembaga, Empat Kapitan, Kisah Rusa dan Kulomang, Persahabatan Bangau dan Tikus, Burung Kakaktua dan Burung Kepondang, Kisah Batu Berdaun, Sepasang Burung Elang di Tifu, Nenek Luhu, Yongker dan Bulu Pamali. Dari kesembilan dongeng provinsi Maluku, penulis memetakan ke dalam 5 jenis dongeng yaitu: Legenda, Mitos, Fabel, Parabel dan Sage. Selain kelima jenis dongeng tersebut, ada sebuah irisan antar jenis dongeng yakni Legenda Mitos. Simpulan pemetaan jenis dongeng provinsi Maluku adalah sebanyak 3 buah dongeng jenis Fabel atau sebesar 34\%, jenis Parabel sebanyak 2 buah atau sebesar 22\%, sedangkan jenis Legenda Mitos dan Legenda Mitos masingmasing sebanyak 1 buah atau sebesar $11 \%$. 

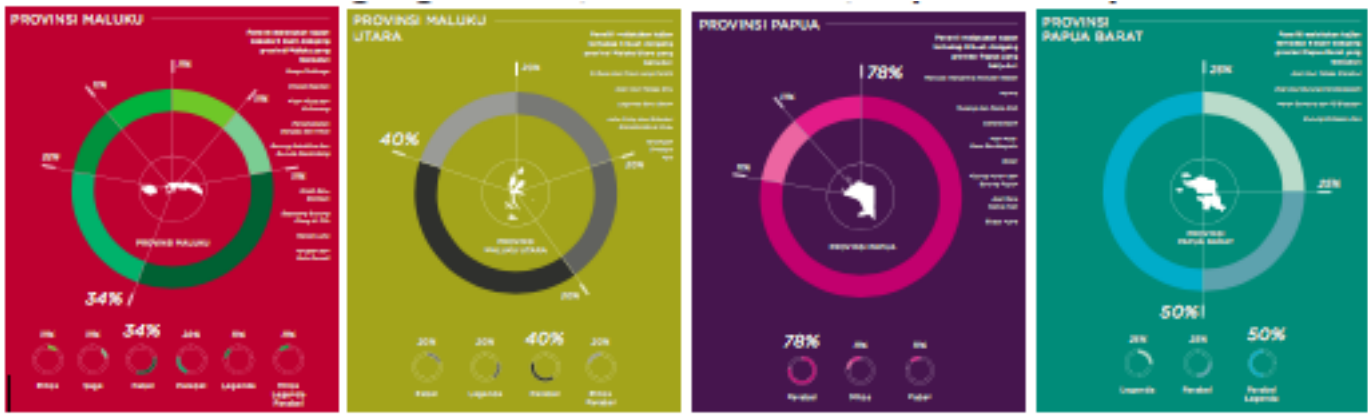

Gambar 7. Infografis Pemetaan Jenis Dongeng 4 Provinsi di Pulau Maluku dan Papua

[Sumber: Dokumentasi Penulis, 2019]

Penulis melakukan kajian terhadap 5 buah dongeng provinsi Maluku Utara yang berjudul: Si Rusa dan Ciput yang Cerdik, Asal Usul Telaga Biru, Legenda Batu Belah, Jafar Sidiq dan Bidadari Berselendang Ungu, Terompah Entaapo Apo. Dari kelima dongeng provinsi Maluku Utara, penulis memetakan ke dalam 3 jenis dongeng yaitu: Legenda, Fabel dan Parabel. Selain ketiga jenis dongeng tersebut, ada sebuah irisan antar jenis dongeng yakni Mitos Parabel. Simpulan pemetaan jenis dongeng provinsi Maluku Utara adalah sebanyak 2 buah dongeng jenis Parabel atau sebesar 40\%, sedangkan jenis Legenda, Fabel dan Mitos Parabel masing-masing sebanyak 1 buah atau sebesar $20 \%$.

Penulis melakukan kajian terhadap 9 buah dongeng provinsi Papua yang berjudul: Manusia menjelma menjadi Hewan, Mamle, Topeng dan Pesta Roh, Cendrawasih, Asal Mula Desa Randuayaivi, Biwar, Kucing Hutan dan Burung Puyuh, Asal Mula Nama Irian, Buaya Ajaib. Dari kesembilan dongeng provinsi Papua, penulis memetakan ke dalam 3 jenis dongeng yaitu: Mitos, Parabel dan Fabel. Simpulan pemetaan jenis dongeng provinsi Papua adalah sebanyak 7 buah dongeng jenis Parabel atau sebesar 78\%, sedangkan jenis Mitos dan Fabel masing-masing sebanyak 1 buah atau sebesar $11 \%$.

Penulis melakukan kajian terhadap 4 buah dongeng provinsi Papua Barat yang berjudul: Asal Usul Telaga Werabur, Asal Usul Burung Cenderawasih, Merak Semana dan 10 Bidadari, Burung Entaapo Apo. Dari keempat dongeng provinsi Papua Barat, penulis memetakan ke dalam 2 jenis dongeng yaitu: Legenda dan Parabel. Selain kedua jenis dongeng tersebut, ada sebuah irisan antar jenis dongeng yakni Legenda Parabel. Simpulan pemetaan jenis dongeng provinsi Papua Barat adalah sebanyak 2 buah dongeng jenis Legenda Parabel atau sebesar 50\%, sedangkan jenis Legenda dan Parabel masing-masing sebanyak 1 buah atau sebesar $25 \%$.

\subsection{Temuan Penelitian}

Hasil temuan dalam studi literatur terhadap 353 buah judul dongeng nusantara dari 34 provinsi di Indonesia yang sudah dipublikasikan adalah adanya jenis-jenis dongeng baru sebagai elaborasi dari 2 jenis dongeng sebelumnya. Adapun jenis-jenis dongeng tersebut dapat dilihat pada gambar dibawah ini. 


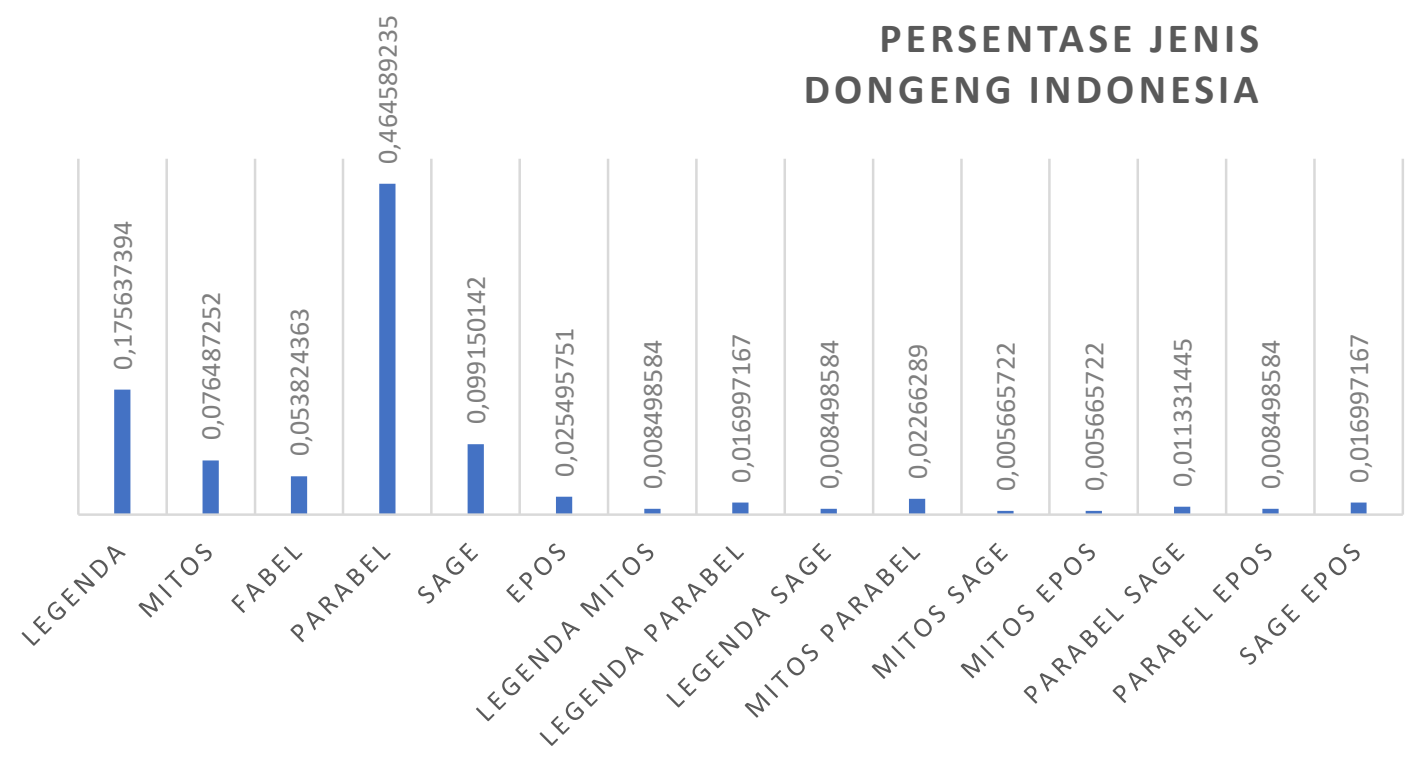

Gambar 8. Presentasi Pemetaan Jenis Dongeng Nusantara [Sumber: Dokumentasi Penulis, 2019]

Gambar 8 di atas merupakan grafik temuan penelitian terhadap jenis dongeng nusantara yang pada awalnya merujuk pada 6 jenis menjadi 15 jenis dongeng Nusantara. Adapun 15 jenis dongeng Nusantara terdiri dari 6 jenis sebelumnya; Legenda, Mitos, Fabel, Parabel, Sage dan Epos menjadi bertambah antara lain; Legenda-Mitos, LegendaParabel, Legenda-Sage, Mitos-Parabel, Mitos-Sage, Mitos-Epos, Parabel-Sage, ParabelEpos dan Sage-Epos.

Temuan ini berdasarkan kajian yang dilakukan penulis pada tiap-tiap dongengnya memiliki ciri-ciri 2 jenis dongeng yang sama kuat. Legenda-Mitos merupakan jenis dongeng yang menceritakan suatu peristiwa yang menghasilkan sebuah artefak dan mengandung nilai magis atau religius yang diyakini oleh masyarakat hingga saat ini. Legenda-Parabel merupakan jenis dongeng yang menceritakan suatu peristiwa yang menghasilkan sebuah artefak dimana cerita dalam dongeng sarat nilai Pendidikan. Legenda-Sage merupakan jenis dongeng yang menceritakan suatu peristiwa yang menghasilkan sebuah artefak dimana cerita dongeng terkait dengan kesejarahan. MitosParabel merupakan jenis dongeng yang mengandung nilai magis atau religius yang diyakini oleh masyarakat hingga saat ini dan ceritanya sarat dengan nilai Pendidikan. Mitos-Sage merupakan jenis dongeng yang mengandung nilai magis atau religius yang diyakini oleh masyarakat hingga saat ini dimana cerita dongeng terkait dengan kesejarahan. Mitos-Epos merupakan jenis dongeng yang mengandung nilai magis atau religius yang diyakini oleh masyarakat hingga saat ini dimana tokoh dari cerita memiliki sifat kepahlawanan. Parabel-Sage merupakan jenis dongeng yang sarat nilai Pendidikan dan terkait dengan kesejarahan. Parabel-Epos merupakan jenis dongeng yang sarat nilai Pendidikan dimana tokoh dari cerita memiliki sifat kepahlawanan. Sage-Epos merupakan jenis dongeng yang terkait dengan kesejarahan dimana tokoh dari cerita memiliki sifat kepahlawanan 


\section{KESIMPULAN}

Simpulan dari penelitian ini adalah dongeng sebagai warisan tradisi lisan nenek moyang bangsa Indonesia harus dijaga dan dilestarikan terutama oleh generasi $Z$ yang dalam waktu 10-20 tahun kedepan akan menjadi tulang punggung bangsa Indonesia. Sehingga menjadi sangat penting mereka mengetahui dan mewarisi tradisi lisan berupa dongeng Indonesia. Pemetaan jenis dongeng nusantara dalam bentuk infografis mampu menarik perhatian generasi $Z$ untuk mengetahui lebih jauh terhadap pemetaan jenis dongeng nusantara. Hal ini diketahui dari reaksi kelompok eksperimen pada penelitian tahap ketiga saat focus group discussion (FGD). Sikap antusias yang ditunjukkan generasi $Z$ pada FGD membuktikan perlu adanya treager/pemicu atau pemantik dalam memberikan informasi.

Dari 353 buah dongeng Indonesia yang dikaji, penulis menyimpulkan jenis dongeng Indonesia antara lain: Legenda (62), Mitos (27), Fabel (19), Parabel (165), Sage (35), Epos (9). Selain itu ada irisan antara kedua jenis dongeng seperti: Legenda Mitos (3), Legenda Parabel (6), Legenda Sage (3), Mitos Parabel (8), Mitos Sage (2), Mitos Epos (2), Parabel Sage (4), Parabel Epos(3), Sage Epos (6).

Jenis Parabel yakni dongeng bersifat mendidik sebanyak lebih dari $46.45 \%$, Legenda yakni dongeng yang menceritakan terjadinya sesuatu dan memiliki bukti artefaknya sebanyak $17.5 \%$, Fabel yakni dongeng yang menokohkan binatang seperti layaknya manusia sebanyak 5.4\%, Mitos yakni dongeng yang berkaitan dengan religi, mistis dan ritualnya masih dilakukan hingga saat ini sebanyak 7.6\%, Epos yakni dongeng yang menceritakan tentang kepahlawanan dari tokoh untuk kemaslahatan orang banyak sebanyak lebih dari $2.5 \%$, dan Sage yakni dongeng yang menceritakan sebuah sejarah sebanyak lebih dari $9.9 \%$.

Selain keenam jenis dongeng di atas terdapat beberapa irisan jenis dongeng diantaranya: Legenda Mitos sebanyak $0.8 \%$, Legenda Parabel sebanyak 1.7\%, Legenda Sage sebanyak 0.8\%, Mitos Parabel sebanyak 2.3\%, Mitos Sage sebanyak 0.56\%, Mitos Epos sebanyak 0.56\%, Parabel Sage sebanyak 1.1\%, Parabel Epos sebanyak 0.8\%, dan Sage Epos 1.7\%.

Pemetaan jenis dongeng nusantara yang baru dari hasil kajian literatur terhadap 353 buah judul dongeng adalah sebagai berikut: Legenda (62 dongeng), Mitos (27 dongeng), Fabel (19 dongeng), Parabel (165 dongeng), Sage (35 dongeng), Epos (9 dongeng). Selain itu ada irisan antara kedua jenis dongeng seperti: Legenda-Mitos ( 3 dongeng), LegendaParabel ( 6 dongeng), Legenda-Sage ( 3 dongeng), Mitos-Parabel ( 8 dongeng), Mitos-Sage ( 2 dongeng), Mitos-Epos ( 2 dongeng), Parabel-Sage (4 dongeng), Parabel-Epos (3 dongeng), Sage-Epos (6 dongeng).

Berdasarkan pemetaan yang dilakukan penulis terhadap jenis dongeng nusantara, ada perkembangan jenis dongeng nusantara. Jika pada awalnya penulis merujuk pada 6 jenis, ternyata setelah melakukan kajian literatur penulis menemukan adanya perkembangan pada jenis dongeng nusantara menjadi 15 jenis. Simpulan-simpulan ini 
masih memerlukan penelitian lanjutan agar memiliki kontribusi dalam perkembangan ilmu pengetahuan khususnya bidang Bahasa dan Sastra maupun Desain Komunikasi Visual. Namun, hasil penelitian ini diharapkan dapat memantik adanya peluang integrasi antar ilmu pengetahuan untuk melakukan penelitian lanjutan secara bersama.

\section{DAFTAR PUSTAKA}

Bencsik, A., Csikos, G., \& Juhaz, T. (2016). Y and Z Generations at Workplaces. Journal of Competitiveness, 8(3), 90-106.

Bencsik, A., \& Machova, R. (2016). Knowledge Sharing Problems from the Viewpoint of Intergeneration Management. In ICMLG2016 - 4th International

Conferenceon Management, Leadership and Governance: ICMLG. (2016). Academic Conferences and publishing limited.

Creswell, J.W. (2009). Research Design. California: SAGE.

Danandjaja, J. (1984). Folklor Indonesia: Ilmu Gosip, Dongeng dll. Jakarta: PT Grafiti.

Endaswara, S. (2009). Metodologi Penelitian Folklor. Yogyakarta: Medpress

Elmore, T. (2014). How Generation Z Differs from Generation Y. Retrieved July 01, 2015, fromhttp://growingleaders.com/blog/generation-z-differs-generation-y/.

Howe, N., \& Strauss, W. (2000). Millennials rising: The next great generation. New York: Vintage.

Kelle, U., \& Erzberger, C. (2017). Metode Kualitatif dan Kuantitatif. Yogyakarta: Cantrik Pustaka.

Lankow, J., Ritchie, J., Crooks, R. (2002). Infografis: The Power of Visual Storytelling. Jakarta: PT. Gramedia Pustaka Utama

Tashakkori, A., \& Teddie, C. (2010). Mixed Methodology. Yogyakarta: Pustaka Pelajar.

Thompson, S. (1946). The Folktale. New York: The Dryden Press. 